\title{
SS18L1/SSX1 Fusion Gene
}

National Cancer Institute

\section{Source}

National Cancer Institute. SS18L1/SSX1 Fusion Gene. NCI Thesaurus. Code C101072.

A fusion gene that results from a chromosomal translocation $t(X ; 20)(p 11 ; q 13.3)$ which fuses exon 10 of the SS18L1 gene to exon 6 of the SSX1 gene. This rearrangement is associated with synovial sarcoma. 